\title{
Supernumerary Molars and Wisdom Tooth Shape Alterations in Patients with Neurofibromatosis Type 1
}

\author{
Reinhard E. Friedrich ${ }^{1}$, Anika Reul ${ }^{1,2}$ \\ ${ }^{1}$ Department of Oral and Craniomaxillofacial Surgery, Eppendorf University Hospital, University of Hamburg, Hamburg, \\ Germany. \\ ${ }^{2}$ Department of Prosthodontics, Eppendorf University Hospital, University of Hamburg, Hamburg, Germany.
}

\author{
Corresponding Author: \\ Reinhard E. Friedrich \\ Martinistr. 52, 20246 Hamburg \\ Germany \\ Phone: +49-40-74105-3259 \\ E-mail: rfriedrich@uke.de
}

\begin{abstract}
Objectives: The purpose of the present study was the systematic investigation of numerical and morphological aberrations of teeth in the wisdom teeth region in neurofibromatosis type 1 patients.

Material and Methods: The panoramic radiographs of 179 patients were analysed for supernumerary molars and dysplastic wisdom teeth with special reference to facial tumour type. The results were compared to radiographic findings obtained in panoramic radiographs of age- and sex-matched controls.

Results: The total number of dysplastic or supernumerary molars was 21 (17 individuals, 4.75\%) and predominantly a finding of the maxilla (maxilla: 15, mandible: 1, maxilla and mandible: 1). Differences of dental findings between neurofibromatosis type 1 (NF1) patients $(n=15)$ and the control group $(n=2)$ were statistically significant $(\mathrm{P}<0.01)$. All individuals with supernumerary molars were diagnosed as being affected with NF1. This difference achieved statistical significance when it was considered that the event may occur at least once per quadrant, and thus the individual potentially needs to be considered four times $(\mathrm{P}=0.0038)$.

Conclusions: This investigation revealed that supernumerary molars and aberrations in wisdom tooth form are more common in patients than in age- and sex-matched controls. There is no association between these findings and a specific feature of the disease, id est facial manifestation of a trigeminal nerve sheath tumour (plexiform neurofibroma). The cause of this phenomenon is unknown. A review of these dental findings on other neurofibromatosis type 1 study groups should be attempted.
\end{abstract}

Keywords: neurofibromatosis type 1; plexiform neurofibroma; supernumerary teeth; tooth abnormalities; wisdom tooth.

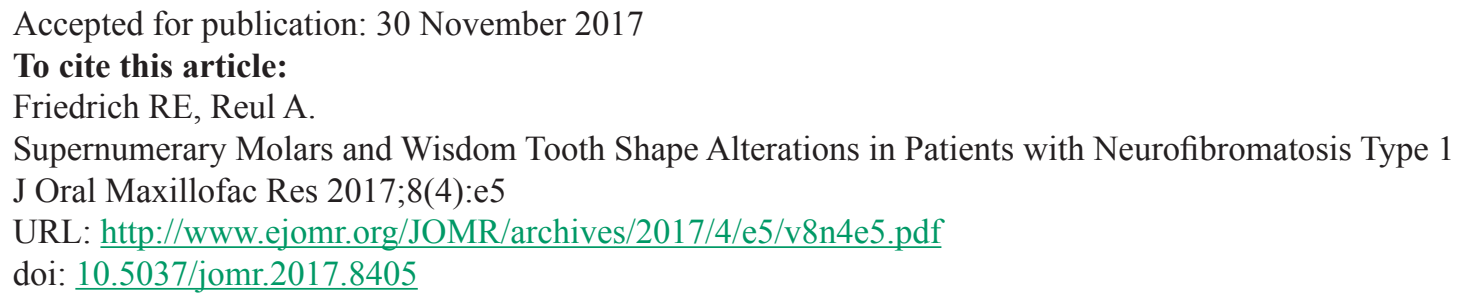




\section{INTRODUCTION}

Neurofibromatosis type 1 (NF1) is a relatively frequently diagnosed inherited tumour predisposition syndrome affecting numerous organs and body systems [1-3]. Neurofibromas are the hallmark of the disease [4]. However, NF1 is also a disease of the bone []ㅡ, including the jaws [6-8]. Earlier reports have already pointed to complex dental and jaw alterations associated with NF1 [7-9]. Further research has shown that the majority of these complex osseous and dental alterations in NF1 are associated with a facial plexiform neurofibroma (FPNF) $[6,10-$ 12]. Retention of teeth and numerical aberrations in dentition have occasionally been reported in NF1 patients $[\underline{2}, \underline{6}, \underline{11}, \underline{13}, \underline{14}]$. However, reports on the oral and maxillofacial manifestations of NF1 deal especially with the description of orofacial soft tissue alterations [ $[7,15-18]$ and complex alterations in dentition $[\underline{19}, \underline{20}]$ which can cause severe disfigurement of affected individuals [2]. Anodontia of second molars on the affected facial side of patients with PNF is recognized a feature of the disease [11]. Attention has also been drawn to the accidental observation of supernumerary teeth [11]. Only a few reports have noted supernumerary molars in NF1 [2124].

Dentition and tooth size may differ from normal values in patients with various syndromes [25-30]. In particular, reduced tooth size can be an indicator of a transition to agenesis [31,32]. However, the sizes of tooth crowns in NF1 patients do not differ from standard values [33]. In that study, an effect of FPNF was explicitly excluded on crown size [3]. On the other hand, macrodontia and the fusion of teeth has been reported in a small series of NF1 patients with defined deletions and mutations of the NF1 gene [34]. All these NF1 patients had no FPNF [34].

Deciduous tooth eruption occurs earlier in NF1affected children than in the normal population [35]. However, the emergence interval of permanent teeth in children and adolescents is not affected by this condition [36]. On the other hand, FPNF has an effect on tooth emergence and the position of teeth in the permanent dentition $[\underline{19}, \underline{33}]$. A frequent and striking finding of FPNF patients is the inhibition of mesial migration of permanent teeth, in particular of molars, resulting in the loss of proximal tooth contact and impressive spacing of teeth [33]. At first sight, this finding would suggest that the hindered mesial movement of the molars leads to developmental disturbances of the last tooth in this series of teeth.
Thus, hypoplasia or even accumulated agenesis of wisdom teeth in the area of PNF would be expected in these patients [11]. The occasional detection of supernumerary molars in the wisdom tooth region on a radiograph of an NF1 patient contradicts this assumption, is a contra-intuitive finding and led to the question as to whether this is an incidental finding or possibly related to the disease.

Therefore, the aim of the study was to answer the question whether supernumerary molar teeth and abnormal tooth forms of the wisdom tooth region are more frequent in patients with neurofibromatosis type 1.

\section{MATERIAL AND METHODS \\ Patient group and control group}

The study was performed on anonymized panoramic radiographs of the jaws of NF1 patients at the Department of Oral and Craniomaxillofacial Surgery, Eppendorf University Hospital. Inclusion criterion of individuals younger than 18 years was that second molars had reached the occlusal plane. The inclusion criterion for the group of NF1 patients was that each individual patient fulfilled the updated diagnostic criteria for this entity $[\underline{1}, \underline{3}, \underline{37}]$. The results were compared with radiographic findings of panoramic radiographs of patients without a diagnosis of NF1 who were investigated for dental and jaw diseases in the Department of Diagnostic Radiology in Dentistry of the University Dental Clinic. Patients with trauma or known genetic disease were excluded from the selection of control radiographs. No further exclusion criteria were applied for the selection of age- and sex-matched controls. The patients of both radiological groups were of Caucasian origin.

\section{Definition of neurofibromatosis type 1}

The clinical diagnosis of NF1 was based on published, generally accepted standards [1]. At least two of the following criteria had to be demonstrated in an individual to establish the diagnosis NF1:

1. Six or more café-au-lait spots over $5 \mathrm{~mm}$ in diameter in prepubertal individuals and over $15 \mathrm{~mm}$ in greatest diameter in postpubertal individuals.

2. Two or more neurofibromas of any type or one plexiform neurofibroma.

3. Freckling in the axillary or inguinal regions.

4. Two or more Lisch nodules (iris hamartomas). 
5. Optic pathway glioma.

6. A distinctive osseous lesion, e.g. sphenoid dysplasia or thinning of long bone cortex, with or without pseudarthrosis.

7. First-degree relative with NF1 by the above criteria.

\section{Definition of neurofibromas}

The term "FPNF-group" describes a group of patients with NF1 who have developed this type of tumour in one or more branches of the trigeminal nerve. This finding was unilateral in all cases. Patients with disseminated cutaneous neurofibromas (DCNF) of the facial region were distinguished from those with FPNF. The term "DCNF" identifies the group of NF1 patients who have not developed a plexiform neurofibroma in the facial region. Further characteristics of these patients are described elsewhere in detail [38].

\section{Definition of tooth anomalies}

Supernumerary teeth of the molar region were defined according to Bolk [31]. Rudimentary teeth in the context of this study describe a radiological finding of a tooth that shows radiopacity equivalent to a tooth structure. The structure is localized in the retromolar region of the jaw. The shape of this structure allows for the definition of longitudinal and transverse axes and the distinction of the crown and root regions. The crown region of these teeth lacks the typical findings of increased radiopacity characteristic of the enamel region or the enamel region is thinned out to a very small layer in the region of the tooth-like structure. The crown shape lies between that of premolars and canines.

A micromorphous tooth is a radiopaque structure that shows the shape of a molar, but the dimensions of this tooth are concentrically shrunken. Structures like crown, pulp and root are distinguishable, but some of these teeth appear to have an incompletely developed root.

In some cases with PNF, the mandible of the affected side was particularly deformed. If the wisdom teeth developed in these jaws, the positions of the teeth were occasionally unrelated to the row of teeth (distal position in angle, not erupted). These teeth were not different in shape and size from the opposite side. However, with some teeth, the roots were arched, which was interpreted as an adaptation of the developing tooth to the deformed jaw. These teeth were not included in the abnormality group of this study.

\section{Radiographic analysis \\ Panoramic radiographs}

Scans were performed with the scanner model Veraview IC5HD (Morita, Kyoto, Japan).

The images were evaluated by the authors, who each have 8 or 27 years of experience in the evaluation of dental radiographs. All radiographs had to clearly represent and completely map the region of interest to be included in the evaluation, that is excluded from the study were blurred or misaligned images or images of incorrectly positioned individuals with incomplete representation of the wisdom tooth region.

The number of teeth in the region of interest was initially determined independently by each of the investigators. The results of the counting were compared with each other. The match of the measured values of this parameter was complete. The determination of the morphology of the wisdom teeth and of the supernumerary molars was carried out in the same way by each individual examiner. In case of disagreement, the case was discussed until consensus was reached. Then the results were compared. The allocation of the tooth shapes according to the abovementioned definition criteria was complete in all cases. Evaluation of all panoramic radiographs were performed in a darkened room. The study NF1 group was further split into subgroups according to type(s) of facial peripheral nerve sheath tumour(s), i.e. DCNF vs. FPNF.

This analysis relies on radiographic pictures only. No information was obtained concerning the history of tooth extraction in the region of interest. This examination condition applies to both study groups. Therefore, the results of the radiographic findings in both groups are comparable within this study, because the same selection conditions applied to both groups for the preparation of an X-ray image. However, the true prevalence of the findings cannot be derived from this investigation, neither for alterations in wisdom tooth form and structure nor in the number of supernumerary teeth.

\section{Statistical analysis}

All of the measurements were realized by the both examiners. Data were registered in Excel 2015 ${ }^{\mathrm{TM}}$ (Microsoft Corporation, Redmond, USA) and analysed in SPSS 24.0 (IBM, Armonk, USA). Fisher's exact test was used for statistical analysis. Statistical significance level was defined at $\mathrm{P}<0.05$. Parametric data were expressed as mean and standard deviation $(\mathrm{M}[\mathrm{SD}])$. 


\section{Ethics}

This study was accepted by the local authority of Eppendorf University Hospital (appointed by the University of Hamburg) as a prerequisite for the preparation of a medical dissertation in dentistry (AR). All patients gave informed consent regarding the scientific evaluation of radiographic data prior to their treatment in the hospital. These investigations were carried out in accordance with the Hamburg Health Service Act (Hamburgisches Gesundheitsdienstgesetz). This type of study does not require an ethics vote.

\section{RESULTS}

Panoramic radiographs of 179 adolescents and adult patients with NF1 and 179 radiographs of age and sex-matched controls were analysed for morphological and numerical alterations of teeth of the wisdom tooth region (females: 100; males: 79; NF1 patient group: min. 12.83 years, max. 68.89 years, mean 34.84 years; control group: $\min .12 .57$ years, max. 69.13 years, mean 34.41 years).

Supernumerary molars and morphological alterations in wisdom teeth were identified in 17 individuals $(4.75 \%)$ of the whole study population $(\mathrm{n}=358)$. One individual was exclusively affected in the mandible, and in 15 the maxilla was exclusively involved. Both jaws were affected in one individual with NF1.

Nine supernumerary teeth were noted in five patients of this study; all were affected with NF1
(2.79\% individuals of NF1 group). In one patient's radiograph, bilateral maxillary supernumerary molars were almost in the same mesio-distal position than the respective wisdom tooth. These teeth were the only ones that qualified for paramolars (Figure 1).

A total of 21 abnormal teeth (micromorphous, rudimentary, supernumerary) of the wisdom tooth area were noted on panoramic radiographs of these 17 individuals. Out of this group, 15 were patients with NF1 (88.2\%) and two were from the reference group (11.8\%). Only two individuals of the reference group showed a dysmorphic dental finding in the region of interest $(1.1 \%$ of the reference group). This was a statistically significant difference $(\mathrm{P}<0.01)$ of dental findings related to group membership.

With reference to the subgroups of NF1 patients, the whole group of dental findings did not differ between DCNF and FPNF patients (DCNF: 8/112, 7.14\%; FPNF: $7 / 67,10.45 \%$ ) The topography of dental anomalies in the terminal region of dentition in NF1 patients was related to a wisdom tooth in 10 cases and to a supernumerary tooth in five cases (5.6\% and 2.8\% of NF1 group, resp.).

\section{Supernumerary teeth: number and topography}

All NF1-related supernumerary teeth were located distal $(n=7)$ or almost in the same position $(n=2)$ in the tooth row compared to the present wisdom tooth. In this subgroup of NF1 patients with supernumerary wisdom teeth, we identified no dysplastic wisdom tooth adjacent to a supernumerary tooth. Nine supernumerary molars were registered

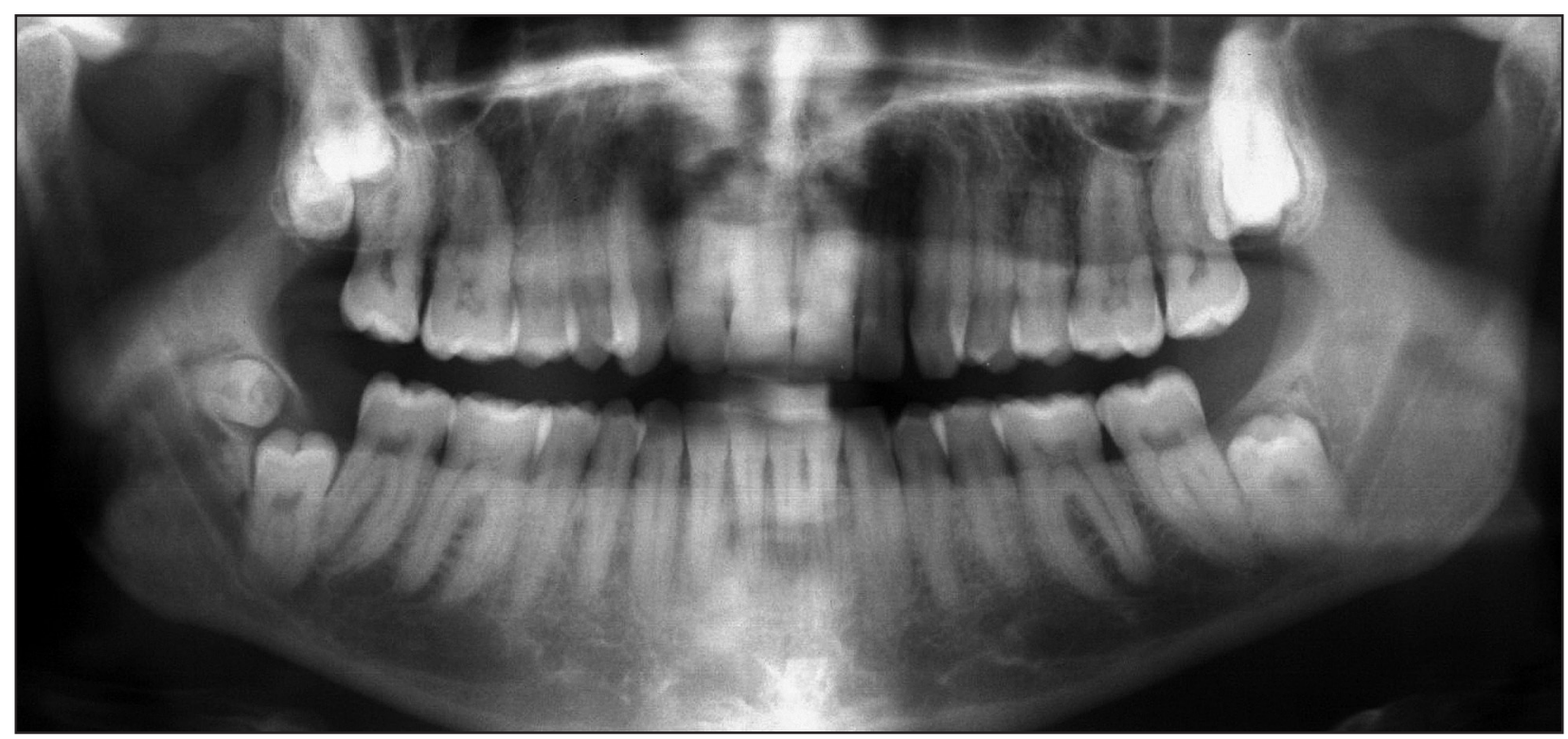

Figure 1. Panoramic radiograph of 35-year-old female patient with neurofibromatosis type 1.

The patient shows no facial plexiform neurofibroma. Supernumerary molars are depicted in the wisdom tooth region of the maxilla on both sides and in the right mandibular ramus. 
in five individuals and were predominantly diagnosed in patients with FPNF (FPNF/DCNF = $4: 1)$. However, the case with the largest number of supernumerary molars was a patient with DCNF. In this case, a bilateral maxillary paramolar and unilateral mandibular distomolar were noted (Figure 1). Prevalence of supernumerary molars showed no statistically significant differences when comparing the number of affected individuals between NF1 group and reference group $(P=0.06$, Fisher's exact test). However, the groups differed in this feature when the individual quadrant was used as the calculation basis $(\mathrm{P}=0.0038$, Fisher's exact test $)$.

\section{Supernumerary teeth: form and shape}

All three supernumerary molars in the one DCNF patient showed a tooth structure with a crown with a size that matched the size of the wisdom tooth (Figure 1). Two further patients had two supernumerary teeth each in the upper jaw (both FPNF). The one patient of the DCNF group with this finding had rudimentary teeth in both locations. The other patient with bilateral maxillary supernumeraries showed a rudimentary tooth 29 on the PNF affected side at the age of 16 years. A consecutive OPG was performed at the age of 18 years that disclosed a second distomolar with incomplete root formation in the right maxilla. A further patient of the FPNF group showed a distomolar of the right mandibular side, contralateral to the FPNF (Figure 2). This was the only patient of the whole sample with only a mandibular distomolar.

\section{Types of altered wisdom tooth morphology}

Rudimentary wisdom teeth were diagnosed in four individuals (reference group: 1; NF1 group: 3) and micromorphous wisdom teeth were diagnosed in six individuals (reference group: 1; NF1 group: 5). Morphology of the wisdom tooth of one individual (NF1 group) was somewhat in-between a rudimentary and a micromorphous tooth. A special case was an individual where it was possible to identify a structure with the radiological opacity of a tooth, but it was horizontally situated outside of the bone and completely embedded in a radiotranslucent structure equivalent to soft tissue. This increased soft tissue mass had already replaced the maxillary alveolar process in a cove-like pattern. The figure was interpreted as the radiological equivalent of an oral manifestation of FPNF at this site.

All in all, 10 individuals had a conspicuous wisdom tooth in the NF1 group and only two in the reference

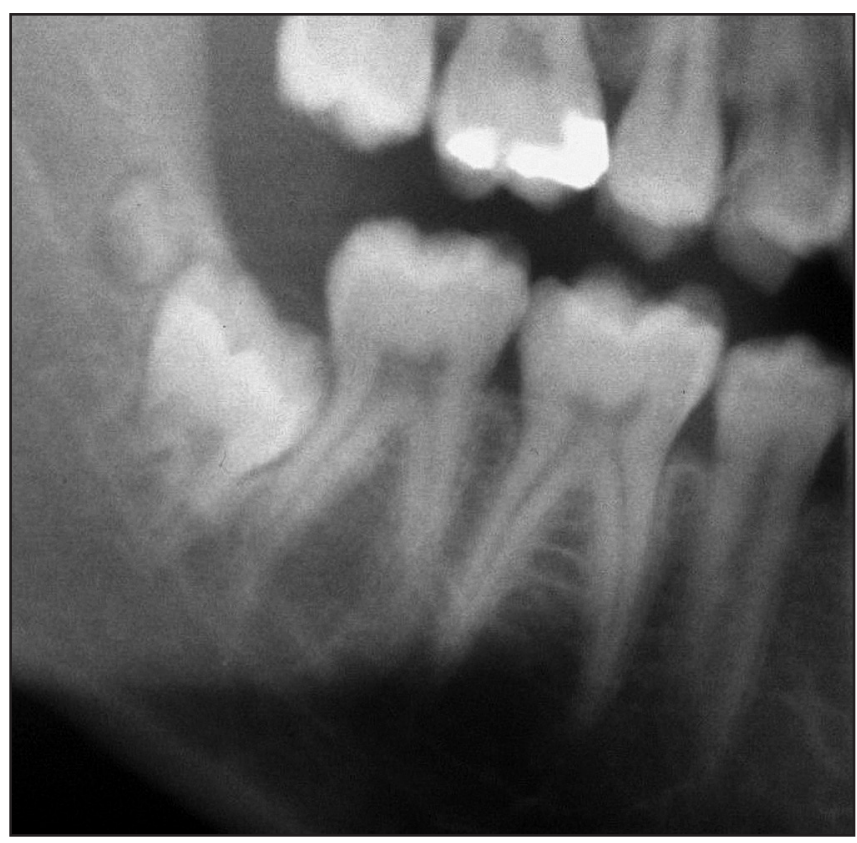

Figure 2. Cropped image of panoramic radiograph reveals supernumerary tooth distal to the emerging right mandibular wisdom tooth in a 16-year-old male affected with left sided facial plexiform neurofibroma.

group. This difference was statistically significant $(\mathrm{P}<$ 0.05 ). It is noteworthy that, in every individual, only one wisdom tooth showed this deviant morphology.

\section{Rudimentary third molars}

Rudimentary third molars were identified in one case of the reference group. The only wisdom tooth in this patient was retained in the bone and showed an extremely short root. However, the dentition of this reference group patient showed further dental anomalies, i.e. aplasia of one second permanent premolar. In the NF1 patient group, the common feature of altered wisdom teeth shape was an extremely reduced volume with small vertical and mesio-distal dimensions, and conical root formation.

\section{Micromorphous teeth}

Micromorphous teeth were identified three times in the group with DCNF and twice in the FPNF group. This finding was recorded in only one case of the reference group. All these micromorphous wisdom teeth were located in the maxilla. One of the FPNF patients showed a micromorphous wisdom tooth on the PNF-affected side, and the other contralateral to this facial tumour.

Results are summarized in Table 1 and Table 2 provides a review of selected studies on supernumerary molars in different populations. 
Table 1. Micromorphous and rudimentary wisdom teeth and supernumerary molars. Numbering of teeth according to Federation Dentaire International

\begin{tabular}{|c|c|c|c|c|c|c|c|c|}
\hline \multirow[b]{2}{*}{ Id No. } & \multirow{2}{*}{$\begin{array}{c}\text { Age } \\
\text { (years) }\end{array}$} & \multirow[b]{2}{*}{ Sex } & \multirow[b]{2}{*}{ Group } & \multirow[b]{2}{*}{ Jaw } & \multicolumn{3}{|c|}{ Affected tooth and type of tooth deformity } & \multirow[b]{2}{*}{ Remarks } \\
\hline & & & & & $\begin{array}{l}\text { Rudimentary } \\
\text { wisdom tooth }\end{array}$ & $\begin{array}{l}\text { Micromorphous } \\
\text { wisdom tooth }\end{array}$ & $\begin{array}{c}\text { Supernumerary } \\
\text { molar }\end{array}$ & \\
\hline 287 & 17 & $\mathrm{~F}$ & Ref. & Maxilla & 28 & - & - & No further wisdom tooth developed, aplasia of lower right second premolar, persistent deciduous molar. \\
\hline 206 & 26 & $\mathrm{~F}$ & Ref. & Maxilla & - & 18 & - & - \\
\hline 25 & 35 & F & DCNF & $\begin{array}{c}\text { Maxilla and } \\
\text { mandible }\end{array}$ & - & - & $19,29,49$ & Facial region: DCNF patient; extensive PNF of right breast and thorax region, maxillary supernumerary teeth in paramolar position. \\
\hline 52 & 39 & M & DCNF & Maxilla & 28 & \multirow{3}{*}{ - } & \multirow{3}{*}{ - } & \multirow{3}{*}{ - } \\
\hline 60 & 22 & $\mathrm{M}$ & DCNF & Maxilla & 18 & & & \\
\hline 122 & 41 & $\mathrm{M}$ & DCNF & Maxilla & 18 & & & \\
\hline 175 & 31 & $\mathrm{M}$ & DCNF & Maxilla & \multirow{3}{*}{ - } & 28 & \multirow{3}{*}{ - } & \multirow{3}{*}{ Conical molar in tuber region. } \\
\hline 66 & 35 & $\mathrm{M}$ & DCNF & Maxilla & & 28 & & \\
\hline 87 & 33 & M & DCNF & Maxilla & & 18 & & \\
\hline 154 & 26 & $\mathrm{~F}$ & DCNF & Maxilla & - & 18 & - & Mixed type of tooth deformity (microdont and peg-shaped). \\
\hline 15 & 18 & F & FPNF & Maxilla & - & - & 19,29 & $\begin{array}{l}\text { FPNF of left facial region extends into the skin region of all three trigeminal nerve branches; right upper distomolar developed } \\
\text { during a period of three years after extraction of right upper third molar. }\end{array}$ \\
\hline 50 & 21 & $\mathrm{M}$ & FPNF & Maxilla & 18 & - & - & Localized maxillary bone reduction in region of rudimentary tooth, tooth not embedded in bone, FPNF: hemifacial, right side. \\
\hline 136 & 24 & M & FPNF & Maxilla & - & 18 & - & FPNF: hemifacial, left side. \\
\hline 82 & 28 & M & FPNF & Maxilla & - & 18 & - & FPNF: orbitotemporal and cheek, right side. \\
\hline 111 & 25 & $\mathrm{M}$ & FPNF & Maxilla & - & - & $19,<$ br $/>29$ & FPNF: orbitotemporal and cheek, right side. \\
\hline 29 & 29 & $\mathrm{~F}$ & FPNF & Maxilla & - & - & 29 & FPNF: cheek, left side. \\
\hline 79 & 16 & M & FPNF & Mandible & - & - & 49 & FPNF: orbitotemporal and cheek of left side. \\
\hline
\end{tabular}

Id No. = identity number; $\mathrm{F}=$ female; $\mathrm{M}$ = male; Ref. = reference group; $\mathrm{DCNF}=$ disseminated cutaneous neurofibroma, $\mathrm{FPNF}=$ facial plexiform neurofibroma.

Table 2. Selected studies describing the frequency of distomolars in humans. Prevalence of distomolars in radiological studies of non-syndromic patients. Panoramic views in publications after 2002 only

\begin{tabular}{|c|c|c|c|c|c|c|c|c|c|}
\hline \multirow[b]{2}{*}{ Author(s) } & \multirow[b]{2}{*}{ Year } & \multirow[b]{2}{*}{$\begin{array}{c}\text { Country/ } \\
\text { ethnic group }\end{array}$} & \multirow[b]{2}{*}{$\begin{array}{c}\text { Number of } \\
\text { patients }\end{array}$} & \multirow[b]{2}{*}{$\begin{array}{c}\text { Age/mean } \\
\text { values (years) }\end{array}$} & \multicolumn{4}{|c|}{ Number of distomolars } & \multirow[b]{2}{*}{ Remarks } \\
\hline & & & & & $\begin{array}{c}\text { Upper jaw: } \\
\text { number or percent }\end{array}$ & $\begin{array}{c}\text { Lower jaw: } \\
\text { number or percent }\end{array}$ & $\begin{array}{c}\text { Total } \\
\text { (individuals) }\end{array}$ & Percent & \\
\hline Stafne [39] & 1932 & USA & 48550 & $\begin{array}{l}\text { 40, not further } \\
\text { specified }\end{array}$ & 131 & 10 & 141 & 0.29 & Micromorphous and conical in shape in maxilla, micromorphous or of equal size in mandible \\
\hline Rajab and Hamdan [40] & 2002 & Jordan & 152 & $10.1+/-1.9$ & 0 & 0 & 0 & 0 & One paramolar registered \\
\hline Harris and Clark [43] & 2008 & $\begin{array}{c}\text { North } \\
\text { Americans }\end{array}$ & 1700 & $\begin{array}{c}12-18, \text { not } \\
\text { further specified }\end{array}$ & 20 & 8 & 18 & 1.06 & Significantly more black Americans affected, distomolar the most frequent site of supernumerary teeth in this group \\
\hline Fernández Montenegro et al. [45] & 2006 & Spain & 36057 & $17.11+/-10.53$ & n.d. & n.d. & 26 & 0.07 & - \\
\hline Fardi et al. [46] & 2011 & Greece & 1239 & $33+/-15.71$ & n.d. & n.d. & 4 & 0.32 & - \\
\hline Martínez-González et al. [48] & 2012 & Spain & 13557 & $14-70(26.7)$ & $63.6 \% \%^{\mathrm{a}}$ & $15.6 \% \%^{\mathrm{a}}$ & $137^{\mathrm{b}}$ & 0.96 & Three or more supernumerary molars in $6.1 \%$ of participants \\
\hline Keil and Speth-Eschenbrenner [50] & 1963 & Germany & 3400 & n.d. & 4 & no & 4 & 0.1 & Male/female 1:1 \\
\hline Kara et al. [53] & 2012 & Turkey & 104902 & 23.45 & $186(53 \%)$ & $35(10 \%)$ & 221 & 0.21 & Two $(0.7 \%)$ patients had three supernumerary molar teeth \\
\hline Bereket et al. [54] & 2015 & Turkey & 111293 & 22.71 & 222 & 24 & 204 & 0.21 & Further six patients had $5^{\text {th }}$ molars in a quadrant \\
\hline Kaya et al. [55] & 2015 & Turkey & 10111 & $\begin{array}{c}>18, \text { not further } \\
\text { specified }\end{array}$ & 25 & 2 & 26 & 0.26 & Two cases with bilateral supernumerary molars, one case with distomolars in both jaws \\
\hline Amini et al. [56] & 2013 & Iran & 3374 & $13.9+/-2.7$ & 0 & 0 & 0 & - & Explicitly noted absence of distomolars \\
\hline
\end{tabular}

aPercentage relative to total number of supernumerary molars.

${ }^{b}$ Total number of distomolars.

n.d. $=$ not detailed. 


\section{DISCUSSION}

This study demonstrated a statistically significant difference in the number of radio-morphological alterations of wisdom teeth in terms of shape and form and the number of supernumerary molars in patients with NF1 compared to a sex- and age-matched control group. Supernumerary molars were only diagnosed in patients affected by this tumour predisposition syndrome. The dysplastic dental findings were more frequently diagnosed in the maxilla. Neither the dysplasia of wisdom teeth nor the development of supernumerary molars depends on the presence or absence of a certain type of tumour. However, supernumerary teeth occurred more frequently in the FPNF group. In the case of FPNF, the dysplastic dental finding may be diagnosed both equilaterally and contralaterally to the facial tumour.

Improper positioning of NF1 patients may lead to radiological artefacts, in particular misinterpretation of the geometry of both teeth and bone on panoramic radiographs [7]. Therefore, the interpretation of panoramic radiographs in NF1 patients has to be performed with caution, in particular in those affected with FPNF and consecutive osseous malformations of the jaws and adjacent skull [7]. One-sided deviation from the normal, symmetrical curve-shaped bone course to which the X-ray source and the detection apparatus are set can lead to distortions of the image of bones and teeth [7]. Therefore, during the examination of radiographs, care was taken as to whether group-wise asymmetries of the tooth size and shape were found when comparing site-specific jaw findings. This finding could indicate deviation of a jaw side from the center of the X-ray path. However, a correct comparison of the hard tissue findings was possible in all cases.

Supernumerary teeth are a well-recognized finding of human dentition [31]. Stafne [39] estimated incidence of supernumerary teeth irrespective of site around $3 \%$ and that of supernumerary molars at $0.41 \%$ (including both paramolars and distomolars; $0.29 \%$ for distomolars). However, not all authors give clear definitions of what they mean by supernumerary teeth and thus the transition to odontomas can be difficult to decide [40]. Supernumerary teeth are predominantly identified in the anterior jaw regions, preferentially affect the maxilla [40-42], and are more frequently diagnosed in males compared to females [42]. However, on the basis of very accurate studies, it was pointed out that this assessment could be biased because the majority of epidemiological studies performed in this field have investigated individuals of white racial origin $[43,44]$. Indeed, many studies on supernumerary teeth are from Western countries [41, 45-51], but in recent times a growing number of reports have been from the Near and Middle East $[\underline{40}, \underline{52-57]}$. From these studies, it can be deduced that depending on the individual study, both men and women may preferentially develop distomolars. Furthermore, the predilection of jaw regions for this phenomenon may vary considerably (Table 2). At least some studies from Asia also support the assumption that supernumerary teeth develop preferentially in the front region of the dentition, e.g. a study from China [42], and the finding of distomolars is discussed as a very rare phenomenon in the Japanese population [58].

A recent Spanish panoramic radiograph study on this subject calculated the prevalence of supernumeraries without consideration of jaw site as $1.05 \%$, but the age characteristics of the study group were not communicated [59]. The age characteristics of the study groups in this research area are important because supernumerary teeth in the molar region may rarely be diagnosed, even in children [41], and it is reasonable to assume that the number of missing teeth will likely rise in a study group of elderly people. Table 2 refers to two studies that explicitly point out that they have not shown any distomolars in their investigation. This finding may be due to the age structure of the study population (age $<20$ years). In fact, a true epidemiological estimate of the number of supernumerary teeth in the molar region is more likely derived from a cohort of adolescent and adult subjects. However, there is apparently no definite time span during the development of the dentition and beyond this time in which the development of supernumerary tooth in the molar region can be expected $[\underline{60}, \underline{61}]$. In the Spanish study mentioned above, upper distomolar region was the most frequently diagnosed region where supernumerary teeth had developed, and males were more frequently affected than females [59]. On the other hand, Liu et al. [42] performed a study in China based on a cone-beam computed tomography and reported 487 cases with supernumerary teeth. They noted only five cases where this anomaly of the tooth number was diagnosed in the molar region $(1.03 \%$; maxilla: 3, mandible: 2). No further specification of data was provided, neither topography nor distribution by gender of molar supernumeraries [42]. Furthermore, another Spanish examination reported an almost identical number of supernumerary molars in females and males in a large group of patients $(67: 63$ individuals) [4ㅇ].

Shahzad and Roth [44] analysed panoramic radiographs from a cohort of employees of an US 
airbase in Japan and identified fourth molars in 2.2\% with a preference for maxillary supernumeraries. There was no difference in fourth molar prevalence between males and females. However, the genders were not equally distributed in their study group. The authors described maxillary supernumeraries to be typically peg-shaped and small, while mandibular ones resembled miniature mandibular third molars [44]. Interestingly, these authors noted that about twothirds of the fourth molars in their study occurred in black Americans. They pointed to the work of Harris and Clark [43], who had already shown that supernumerary teeth were far more common in black Americans than in white Americans, and that in the group of black Americans, the most frequent appearance among the supernumerary teeth was fourth molars. The respective percentages of patients with distomolar were similar in the group of black Americans and the NF1 group of this study.

Ohata et al. [58] reported about their experience in the diagnosis and treatment of three patients with distomolars. Their morphological study of extracted distomolars revealed normal molar development of "dwarfed" teeth. According to a review of these authors on further studies published in Japanese, incidence of fourth molars in Japan is around 0.02 and $0.16 \%$ and predominantly a finding related to the maxilla.

An Italian study investigated a large number of panoramic radiographs that were selected for morphological and topographical characteristics of posterior supernumerary teeth. These authors registered, out of a whole group of supernumerary molars, only 13 distomolars (prevalence $0.052 \%$ ) [49]. Male to female ratio was $2.5: 1$ and supernumerary molars (both paramolars and distomolars) were more frequently diagnosed in the maxilla [49].

Kaya et al. [55] analysed a large group of panoramic radiographs obtained in a Turkish urban center for the prevalence of distomolars. Distomolars were diagnosed in $0.26 \%$, were more frequently encountered in the maxilla, and showed an equal distribution between men and women. The impaction of supernumeraries was the predominant radiological topography $(83.3 \%)$. Another Turkish study on this subject identified a slightly higher frequency of supernumerary molars in females [53].

Earlier study from Germany reported distomolars in $0.12 \%$ of cases that were evenly distributed to men and women (four patients) [미. This study was based on the evaluation of dental X-rays.

Although numerous studies on the prevalence of supernumerary teeth have been published in the literature, only a few studies are based on the analysis of supernumerary molars, distinguishing between distomolars and paramolars $[\underline{31}, \underline{39}, \underline{48}]$. It has been reported that paramolars are more common than distomolars [49]. On the other hand, MartínezGonzález et al. [48] identified no paramolars in their study. An earlier study revealed that distomolars were twice frequent than paramolars [39]. Our results agree with the findings detailed by Stafne [39]. However, our results are based on a much smaller number of cases.

In the present study, one distomolar occurred on both sides of the maxilla in two cases $(40 \%$ of all distomolar patients; $1.1 \%$ of NF1 patients; $0.55 \%$ of whole study group). This rare finding was also noted by Stafne [39] in one of 141 cases with distomolars $(0.7 \%$ of all distomolars, $0.002 \%$ of the study population).

In the present study, the number of four molars per side of a jaw was never exceeded. This was also explicitly reported by Arslan et al. [52] and agrees with the description of Stafne [39]. One of our cases showed distomolars in both jaws. Shahzad and Roth [44] referred to the high number of distomolars in their group of black Americans. Interestingly, fourth molars were identified in no instances in both the maxilla and mandible [44]. Kaya et al. [55] identified distomolars in both the maxilla and mandible in one out of 10,111 patients.

In cases of supernumerary tooth development, about one in three affected individuals is expected to have a further supernumerary tooth [48]. It is worth mentioning that the number of NF1 patients in this study with more than one distomolar was higher than those with a solitary supernumerary molar. However, this study was restricted to identifying only distomolars on panoramic radiographs, the total number of distomolars in this study was low, and the total number of patients of this study cannot qualify for comparison with large epidemiological studies (Table 2). This is likely the first report explicitly addressing the fact that supernumerary molars occur in NF1 with reference to a relatively large number of patients with adequate radiographs depicting the whole jaw. However, this phenomenon is not new and can be studied on published radiographs to illustrate the complex deformations of the facial skeleton in this disease [으]. In the referred case, the supernumerary upper molar was associated with FPNF and severe malformation of the facial skeleton [60].

In summary of the literature, distomolars are a rare finding in the normal population and can be expected in less than $1 \%$ of a reference population. Table 2 presents a selection of studies on the prevalence of distomolars. 
The aetiology of supernumerary teeth is not clear. The genetic trait of supernumerary teeth not related to a medical syndrome has been documented in single case studies [62]. A recent review on potential aetiologies on supernumerary teeth emphasized the absence of well-founded and convincing theories for the explanation of this multifarious phenomenon [61]. However, the authors concluded that a genetic component in the aetiology of supernumerary teeth is logical to state. They summarized several syndromes for which hyperdontia is recognized and the genetic locus is known. At present, NF1 does not belong to this group of genetically characterized diseases with hyperdontia [61]. Indeed, hypodontia is also known in NF1 [63]. Numerical aberrations of teeth occur in several syndromes. A review on the subject of the association between certain syndromes and supernumerary teeth limited the number of syndromes for which there is strong scientific evidence for the genetic influence on this dental finding to only eight entities [64]. Interestingly, in one of these syndromes with a noticeable association with supernumerary teeth development, called tricho-rhino-phalangeal syndrome type 1 , the number of additional teeth in both jaws was considerable (up to 18 teeth). However, the morphology of teeth predominantly resembled premolars and there were no additional teeth that had developed distal to the third molar [65]. In the order of supernumerary teeth, the teeth which occur in the extension of the tooth row should be considered separately.

The retention of molars and other teeth is a finding that occurs frequently with FPNF of the ipsilateral trigeminal nerve branch $[\underline{6}, \underline{7}, \underline{10}, \underline{13}, \underline{14}]$. Molar teeth appear to be more frequently affected than others [11]. In these cases, the affected mandibular side is typically reduced in both the sagittal and transverse directions $[10,12]$. The incisura semilunaris is deepened in the vertical direction and the mandibular foramen appears enlarged on panoramic radiographs [10-12]. This constellation of osseous findings may offer only a small volume for permanent teeth development. In the maxilla, the tuber region is hypoplastic [11]. Therefore, it would be not surprising to diagnose aplasia of wisdom teeth in patients showing this distinct osseous dysplasia [66]. Indeed, the mandibular form is associated with the agenesis of premolars [67]. However, complete development of all three molars in deformed jaws is well-known for NF1 $[\underline{6}, \underline{12}, \underline{13}]$, although a reduced number of molars in the affected facial region is well-documented [11]. Bone deformity is strictly associated with the spread of FPNF, but this does not necessarily reduce the number of dental anlage. Malformation of molar roots is frequently seen in this situation and is possibly explainable as an adaptation of developing roots to an already dysplastic bone. The deformation of the jaws precedes the development of permanent molars and probably takes place during the fetal and early childhood phases $[\underline{38}, \underline{68}]$. However, dysplastic (supernumerary) molars are also identified in NF1 patients in the jaw opposite to the FPNF.

\section{CONCLUSIONS}

Various abnormalities in the jaw and tooth developments and tooth position belong to the plethora of the findings with neurofibromatosis type 1. As a new finding, numerical aberrations in the wisdom tooth region must be taken into account, especially the quite frequent occurrence of supernumerary molars. The development of facial plexiform neurofibroma cannot explain the numerical and structural anomalies in the wisdom tooth region of neurofibromatosis type 1 patients. The relationship of this finding with the cause of the disease is currently unclear. It is likely that the genetic disposition of the neurofibromatosis type 1 patient contributes to the increased occurrence of malformations in the wisdom tooth region.

\section{ACKNOWLEDGMENTS AND DISCLOSURE STATEMENTS}

The authors report no conflicts of interest related to this study.

\section{REFERENCES}

1. Neurofibromatosis. Conference statement. National Institutes of Health Consensus Development Conference. Arch Neurol. 1988 May;45(5):575-8. [Medline: 3128965]

2. Riccardi VM. Neurofibromatosis. Phenotype, Natural History, and Pathogenesis. 2nd edition. Baltimore: The Johns Hopkins University Press; 1992. p. 30-1, 66, 108-18, 224-50.

3. Ferner RE, Gutmann DH. Neurofibromatosis type 1 (NF1): diagnosis and management. Handb Clin Neurol. 2013;115:93955. [Medline: 23931823] [doi: 10.1016/B978-0-444-52902-2.00053-9]

4. Recklinghausen FD. Über die multiplen Fibrome der Haut und ihre Beziehung zu den multiplen Neuromen. Berlin: Hirschwald; 1882. 
5. Holt JF, Wright EM. The radiologic features of neurofibromatosis. Radiology. 1948 Nov;51(5):647-64. [Medline: 18891292] [doi: 10.1148/51.5.647]

6. Lee L, Yan YH, Pharoah MJ. Radiographic features of the mandible in neurofibromatosis: a report of 10 cases and review of the literature. Oral Surg Oral Med Oral Pathol Oral Radiol Endod. 1996 Mar;81(3):361-7. [Medline: $\underline{8653472]}$ [doi: 10.1016/S1079-2104(96)80338-6]

7. D'Ambrosio JA, Langlais RP, Young RS. Jaw and skull changes in neurofibromatosis. Oral Surg Oral Med Oral Pathol. 1988 Sep;66(3):391-6. [Medline: 3140162] [doi: 10.1016/0030-4220(88)90252-6]

8. Shapiro SD, Abramovitch K, Van Dis ML, Skoczylas LJ, Langlais RP, Jorgenson RJ, Young RS, Riccardi VM. Neurofibromatosis: oral and radiographic manifestations. Oral Surg Oral Med Oral Pathol. 1984 Oct;58(4):493-8. [Medline: 6436765] [doi: 10.1016/0030-4220(84)90350-5]

9. Rushton MA. Case reports: Case no. 91. Neurofibroma affecting jaws. Am Orthodont Oral Surg. 1944 Dec;30(12):790-2. [doi: 10.1016/S0096-6347(44)90174-2]

10. Sailer HF, Künzler A, Makek MS. [Neurofibrohemangiomatous soft tissue changes with pathognomonic mandibular deformity]. Fortschr Kiefer Gesichtschir. 1988;33:84-6. German. [Medline: 3044956]

11. Friedrich RE, Giese M, Schmelzle R, Mautner VF, Scheuer HA. Jaw malformations plus displacement and numerical aberrations of teeth in neurofibromatosis type 1: a descriptive analysis of 48 patients based on panoramic radiographs and oral findings. J Craniomaxillofac Surg. 2003 Feb;31(1):1-9. [Medline: 12553919] [doi: 10.1016/S1010-5182(02)00160-9]

12. Visnapuu V, Peltonen S, Tammisalo T, Peltonen J, Happonen RP. Radiographic findings in the jaws of patients with neurofibromatosis 1. J Oral Maxillofac Surg. 2012 Jun;70(6):1351-7. [Medline: 21856061] [doi: 10.1016/i.joms.2011.06.204]

13. Winters SE, Husser HF, Simard EE, Shebl JJ. Neurofibromatosis (von Recklinghausen's disease) with involvement of the mandible. Report of a case. Oral Surg Oral Med Oral Pathol. 1960 Jan;13:76-9. [Medline: 13845344] [doi: 10.1016/0030-4220(60)90398-4]

14. Gupta SK, Nema HV, Bhatia PL, Sasibabu K, Kesharwani R. The radiological features of craniofacial neurofibromatosis. Clin Radiol. 1979 Sep;30(5):553-7. [Medline: 111891] [doi: 10.1016/S0009-9260(79)80194-4]

15. Maceri DR, Saxon KG. Neurofibromatosis of the head and neck. Head Neck Surg. 1984 Mar-Apr;6(4):842-50. [Medline: 6423572] [doi: 10.1002/hed.2890060407]

16. O'Driscoll PM. The oral manifestations of multiple neurofibromatosis. Br J Oral Surg. 1965 Jul;3(1):22-31. [Medline: 4958015] [doi: 10.1016/S0007-117X(65)80003-8]

17. Friedrich RE, Schmelzle R, Giese M, Mautner VF. Zur Häufigkeit intraoraler weichgeweblicher. Raumforderungen bei Neurofibromatose Typ 1. Dtsch Z Mund Kiefer Gesichts Chir. 1994; 18: 207-9.

18. Geist JR, Gander DL, Stefanac SJ. Oral manifestations of neurofibromatosis types I and II. Oral Surg Oral Med Oral Pathol. 1992 Mar;73(3):376-82. [Medline: 1545973] [doi: 10.1016/0030-4220(92)90139-H]

19. Friedrich RE. Maxillofaziale und orale Neurofibromatose Typ 1 : klinische, radiologische, morphologische und immunhistochemische Untersuchungen als Grundlage der regionalen Tumor- und Wiederherstellungschirugie. Aachen: Shaker Verlag; 2010. [Medline: 101572946]

20. Cunha KS, Rozza-de-Menezes RE, Andrade RM, Almeida L, Janini M, Geller M. Oral manifestations of neurofibromatosis type 1 in children with facial plexiform neurofibroma: report of three cases. J Clin Pediatr Dent. 2015 Winter;39(2):168-71. [Medline: 25823487] [doi: 10.17796/jcpd.39.2.972220046g774534]

21. Freeman MJ, Standish SM. Facial and oral manifestations of familial disseminated neurofibromatosis. Report of a case. Oral Surg Oral Med Oral Pathol. 1965 Jan;19:52-9. [Medline: 14233399] [doi: 10.1016/0030-4220(65)90218-5]

22. Westphal D, Koblin I. [Dental and jaw findings in neurofibromatosis in the maxillofacial region]. Dtsch Zahnarztl Z. 1977 May;32(5):418-20. German. [Medline: 405193]

23. Rittersma J, ten Kate LP, Westerink P. Neurofibromatosis with mandibular deformities. Oral Surg Oral Med Oral Pathol. 1972 May;33(5):718-27. [Medline: 4622799] [doi: 10.1016/0030-4220(72)90439-2]

24. Neville BW, Hann J, Narang R, Garen P. Oral neurofibrosarcoma associated with neurofibromatosis type I. Oral Surg Oral Med Oral Pathol. 1991 Oct;72(4):456-61. [Medline: 1923446] [doi: 10.1016/0030-4220(91)90560-Y]

25. Dalili Z, Adham G. Intraosseous neurofibroma and concurrent involvement of the mandible, maxilla and orbit: report of a case. Iran J Radiol. 2012 Mar;9(1):45-9. [Medline: 23329961] [PMC free article: 3522340] [doi: 10.5812/iranjradiol.6684]

26. Jensen BL, Kreiborg S. Development of the dentition in cleidocranial dysplasia. J Oral Pathol Med. 1990 Feb;19(2): 89-93. [Medline: 2341976] [doi: 10.1111/j.1600-0714.1990.tb00803.x]

27. Atasu M, Dumlu A, Ozbayrak S. Multiple supernumerary teeth in association with cleidocranial dysplasia. J Clin Pediatr Dent. 1996 Fall;21(1):85-91. [Medline: 9161213]

28. Acerbi AG, de Freitas $\mathrm{C}$, de Magalhães $\mathrm{MH}$. Prevalence of numeric anomalies in the permanent dentition of patients with Down syndrome. Spec Care Dentist. 2001 Mar-Apr;21(2):75-8. [Medline: 11484586] [doi: 10.1111/j.1754-4505.2001.tb00230.x]

29. Walker SC, Mattick CR, Hobson RS, Steen IN. Abnormal tooth size and morphology in subjects with cleft lip and/or palate in the north of England. Eur J Orthod. 2009 Feb;31(1):68-75. [Medline: 19073959] [doi: 10.1093/ejo/cjn073] 
30. Cuoghi OA, Topolski F, Perciliano de Faria L, Occhiena CM, Ferreira ND, Ferlin CR, Rogério de Mendonça M. Prevalence of Dental Anomalies in Permanent Dentition of Brazilian Individuals with Down Syndrome. Open Dent J. 2016 Aug 31;10:469-473. [Medline: 27733874] [PMC free article: 5045970] [doi: 10.2174/1874210601610010469]

31. Bolk L. Supernumerary teeth in the molar region in man. Dent Cosmos. 1914;56:154-67.

32. Choi SJ, Lee JW, Song JH. Dental anomaly patterns associated with tooth agenesis. Acta Odontol Scand. 2017 Apr;75(3):161-165. [Medline: 28121195] [doi: 10.1080/00016357.2016.1273385]

33. Friedrich RE, Giese M, Stelljes C, Froeder C, Scheuer HA. Size of tooth crowns and position of teeth concerning the extension of facial plexiform neurofibroma in patients with neurofibromatosis type 1. Anticancer Res. 2012 May;32(5):2207-14. [Medline: 22593511]

34. Kobayashi R, Matsune K, Ohashi H. Fused teeth, macrodontia and increased caries are characteristic features of neurofibromatosis type 1 patients with NF1 gene microdeletion. J Pediatr Genet. 2012 Mar;1(1):25-31. [Medline: 27625798] [PMC free article: 5020916] [doi: 10.3233/PGE-2012-006]

35. Lammert M, Friedrich RE, Friedman JM, Mautner VF, Tucker T. Early primary tooth eruption in neurofibromatosis 1 individuals. Eur J Oral Sci. 2007 Oct;115(5):425-6. [Medline: 17850432] [doi: 10.1111/j.1600-0722.2007.00474.x]

36. Jääsaari P, Visnapuu V, Nyström M, Peltonen S, Peltonen J, Happonen RP. Dental age in patients with neurofibromatosis 1. Eur J Oral Sci. 2012 Dec;120(6):549-52. [Medline: 23167472] [doi: 10.1111/j.1600-0722.2012.01000.x]

37. Gutmann DH, Aylsworth A, Carey JC, Korf B, Marks J, Pyeritz RE, Rubenstein A, Viskochil D. The diagnostic evaluation and multidisciplinary management of neurofibromatosis 1 and neurofibromatosis 2. JAMA. 1997 Jul 2;278(1):51-7. [Medline: 9207339] [doi: 10.1001/jama.1997.03550010065042]

38. Friedrich RE, Lehmann JM, Rother J, Christ G, Zu Eulenburg C, Scheuer HT, Scheuer HA. A lateral cephalometry study of patients with neurofibromatosis type 1. J Craniomaxillofac Surg. 2017 Jun;45(6):809-820. [Medline: 28365079] [doi: 10.1016/j.jems.2017.02.011]

39. Stafne EC. Supernumerary teeth. Dent Cosmos 1932;74:653-9.

40. Rajab LD, Hamdan MA. Supernumerary teeth: review of the literature and a survey of 152 cases. Int J Paediatr Dent. 2002 Jul;12(4):244-54. [Medline: 12121534] [doi: 10.1046/j.1365-263X.2002.00366.x]

41. Bergström K. An orthopantomographic study of hypodontia, supernumeraries and other anomalies in school children between the ages of 8-9 years. An epidemiological study. Swed Dent J. 1977;1(4):145-57. [Medline: 270232]

42. Liu DG, Zhang WL, Zhang ZY, Wu YT, Ma XC. Three-dimensional evaluations of supernumerary teeth using cone-beam computed tomography for 487 cases. Oral Surg Oral Med Oral Pathol Oral Radiol Endod. 2007 Mar;103(3):403-11. [Medline: 17321454 ] [doi: $10.1016 /$ i.tripleo.2006.03.026]

43. Harris EF, Clark LL. An epidemiological study of hyperdontia in American blacks and whites. Angle Orthod. 2008 May;78(3):460-5. [Medline: 18416616] [doi: 10.2319/022807-104.1]

44. Shahzad KM, Roth LE. Prevalence and management of fourth molars: a retrospective study and literature review. J Oral Maxillofac Surg. 2012 Feb;70(2):272-5. [Medline: 21802814] [doi: 10.1016/j.joms.2011.03.063]

45. Fernández Montenegro P, Valmaseda Castellón E, Berini Aytés L, Gay Escoda C. Retrospective study of 145 supernumerary teeth. Med Oral Patol Oral Cir Bucal. 2006 Jul 1;11(4):E339-44. [Medline: 16816819]

46. Fardi A, Kondylidou-Sidira A, Bachour Z, Parisis N, Tsirlis A. Incidence of impacted and supernumerary teeth-a radiographic study in a North Greek population. Med Oral Patol Oral Cir Bucal. 2011 Jan 1;16(1):e56-61. [Medline: 20711166] [doi: 10.4317/medoral.16.e56]

47. Alvira-González J, Gay-Escoda C. Non-syndromic multiple supernumerary teeth: meta-analysis. J Oral Pathol Med. 2012 May;41(5):361-6. [Medline: 22092693] [doi: 10.1111/j.1600-0714.2011.01111.x]

48. Martínez-González JM, Cortés-Bretón Brinkmann J, Calvo-Guirado JL, Arias Irimia O, Barona-Dorado C. Clinical epidemiological analysis of 173 supernumerary molars. Acta Odontol Scand. 2012 Sep;70(5):398-404. [Medline: 22364201] [doi: 10.3109/00016357.2011.629629]

49. Cassetta M, Altieri F, Giansanti M, Di-Giorgio R, Calasso S. Morphological and topographical characteristics of posterior supernumerary molar teeth: an epidemiological study on 25,186 subjects. Med Oral Patol Oral Cir Bucal. 2014 Nov 1; 19(6):e545-9. [Medline: 25129242] [PMC free article: 4259368] [doi: 10.4317/medoral.19775]

50. Keil A, Speth-Eschenbrenner J. Über Zahnanomalien bei 3400 Patienten nach Röntgenstaten. Dtsch Zahn Mund Kieferheilk. 1963;40:360-76.

51. Weise W. Röntgenologische Untersuchungen im Bereich der Distomolaren. Fortschr Kieferorthopäd. 1971 Jun;32(2): 337-44. [doi: 10.1007/BF02170658]

52. Arslan A, Altundal H, Ozel E. The frequency of distomolar teeth in a population of urban Turkish adults: a retrospective study. Oral Radiol 2009 Dec;25:118-22. [doi: 10.1007/s11282-009-0020-2]

53. Kara Mİ, Aktan AM, Ay S, Bereket C, Şener İ, Bülbül M, Ezirganlı Ş, Polat HB. Characteristics of 351 supernumerary molar teeth in Turkish population. Med Oral Patol Oral Cir Bucal. 2012 May 1;17(3):e395-400. [Medline: 22143736] [PMC free article: 3476093] [doi: 10.4317/medoral.17605]

54. Bereket C, Çakır-Özkan N, Şener İ, Bulut E, Baştan Aİ. Analyses of 1100 supernumerary teeth in a nonsyndromic Turkish population: A retrospective multicenter study. Niger J Clin Pract. 2015 Nov-Dec;18(6):731-8. [Medline: 26289509] [doi: 10.4103/1119-3077.154213] 
55. Kaya E, Güngör K, Demirel O, Özütürk Ö. Prevalence and characteristics of non-syndromic distomolars: a retrospective study. J Investig Clin Dent. 2015 Nov;6(4):282-6. [Medline: 25187170] [doi: 10.1111/jicd.12108]

56. Amini F, Rakhshan V, Jamalzadeh S. Prevalence and Pattern of Accessory Teeth (Hyperdontia) in Permanent Dentition of Iranian Orthodontic Patients. Iran J Public Health. 2013 Nov;42(11):1259-65. [Medline: 26171338] [PMC free article: 4499067$]$

57. Patil S, Maheshwari S. Prevalence of impacted and supernumerary teeth in the North Indian population. J Clin Exp Dent. 2014 Apr 1;6(2):e116-20. [Medline: 24790709] [doi: 10.4317/jced.51284]

58. Ohata H, Hayashi K, Iwamoto M, Muramatsu K, Watanabe A, Narita M, Suga K, Takano N, Shibahara T. Three cases of distomolars. Bull Tokyo Dent Coll. 2013;54(4):259-64. [Medline: 24521552] [doi: 10.2209/tdcpublication.54.259]

59. Leco Berrocal MI, Martín Morales JF, Martínez González JM. An observational study of the frequency of supernumerary teeth in a population of 2000 patients. Med Oral Patol Oral Cir Bucal. 2007 Mar 1;12(2):E134-8. [Medline: 17322802]

60. Rath R, Kaur S, Baig SA, Pati P, Sahoo S. Multifocal Head and Neck Neurofibromas with Osseous Abnormalities and Muscular Hypoplasia in a Child with Neurofibromatosis: Type I. Case Rep Radiol. 2016;2016:3980270. [Medline: 27382495] [PMC free article: 4921149] [doi: 10.1155/2016/3980270]

61. Anthonappa RP, King NM, Rabie AB. Aetiology of supernumerary teeth: a literature review. Eur Arch Paediatr Dent. 2013 Oct;14(5):279-88. [Medline: 24068489] [doi: 10.1007/s40368-013-0082-z]

62. Batra P, Duggal R, Parkash H. Non-syndromic multiple supernumerary teeth transmitted as an autosomal dominant trait. J Oral Pathol Med. 2005 Nov;34(10):621-5. [Medline: 16202084] [doi: 10.1111/j.1600-0714.2005.00271.x]

63. Friedrich RE, Grob TJ, Hollants S, Zustin J, Spaepen M, Mautner VF, Luebke AM, Hagel C, Legius E, Brems H. Recurrent multilocular mandibular giant cell granuloma in neurofibromatosis type 1: Evidence for second hit mutation of NF1 gene in the jaw lesion and treatment with curettage and bone substitute materials. J Craniomaxillofac Surg. 2016 Aug;44(8):1054-60. [Medline: 27316856] [doi: 10.1016/j.jcms.2016.05.010]

64. Lubinsky M, Kantaputra PN. Syndromes with supernumerary teeth. Am J Med Genet A. 2016 Oct;170(10):2611-6. [Medline: 27250821] [doi: 10.1002/ajmg.a.37763]

65. Kunotai W, Ananpornruedee P, Lubinsky M, Pruksametanan A, Kantaputra PN. Making extra teeth: Lessons from a TRPS1 mutation. Am J Med Genet A. 2017 Jan;173(1):99-107. [Medline: 27706911] [doi: 10.1002/ajmg.a.37967]

66. Heervä E, Peltonen S, Pirttiniemi P, Happonen RP, Visnapuu V, Peltonen J. Short mandible, maxilla and cranial base are common in patients with neurofibromatosis 1. Eur J Oral Sci. 2011 Apr;119(2):121-7. [Medline: 21410551] [doi: 10.1111/j.1600-0722.2011.00811.x]

67. Bertl MH, Bertl K, Wagner M, Gahleitner A, Stavropoulos A, Ulm C, Mitteroecker P. Second premolar agenesis is associated with mandibular form: a geometric morphometric analysis of mandibular cross-sections. Int J Oral Sci. 2016 Dec 16;8(4):254-260. [Medline: 27857074] [PMC free article: 5168418] [doi: 10.1038/ijos.2016.41]

68. Kjær I. Etiology-Based Dental and Craniofacial Diagnostics. Hoboken: Wiley-Blackwell; 2016 Oct. [doi: $10.1002 / 9781118912089$ ]

\section{To cite this article:}

Friedrich RE, Reul A.

Supernumerary Molars and Wisdom Tooth Shape Alterations in Patients with Neurofibromatosis Type 1

J Oral Maxillofac Res 2017;8(4):e5

URL: http://www.ejomr.org/JOMR/archives/2017/4/e5/v8n4e5.pdf

doi: $10.5037 /$ jomr.2017.8405

Copyright (C) Friedrich RE, Reul A. Published in the JOURNAL OF ORAL \& MAXILLOFACIAL RESEARCH (http://www.ejomr.org), 31 December 2017.

This is an open-access article, first published in the JOURNAL OF ORAL \& MAXILLOFACIAL RESEARCH, distributed under the terms of the Creative Commons Attribution-Noncommercial-No Derivative Works 3.0 Unported License, which permits unrestricted non-commercial use, distribution, and reproduction in any medium, provided the original work and is properly cited. The copyright, license information and link to the original publication on (http://www.ejomr.org) must be included. 